\title{
Polyvalent Carbocyanine Molecular Beacons for Molecular Recognitions
}

\author{
Yunpeng Ye, Sharon Bloch, and Samuel Achilefu* \\ Department of Radiology, Washington University School of Medicine, St. \\ Louis, MO 63110 \\ *E-mail Address: achilefus@wustl.edu
}

\section{Experimental}

Chemicals: 2-(1H-Benzotriazol-1-yl)1,1,3,3-tetramethyluronium hexafluorophosphate (HBTU) and N-hydroxybenzotriazole (HOBt) were purchased from AnaSpec (San Jose, CA). Trifluoroacetic acid (TFA) and DIEA were purchased from Advanced ChemTech (Louisville, KY). Glutaconaldydyde dianilide monohydrochloride were purchased from Lancaster. Dichloromethane (DCM), N,N-dimethyformamide (DMF), methanol and acetonitrile were from purchased from Fisher Scientific. Other commercial chemicals were purchased from Sigma-Aldrich.

Purification and identification: Analytical reverse-phase high performance liquid chromatography (HPLC) was performed on Vydac C-18 columns $(250 \times 4.6 \mathrm{~mm})$ at a flow rate of $1.0 \mathrm{~mL} / \mathrm{min}$ and semipreparative HPLC was performed on a similar column $(25 \times 2.2 \mathrm{~cm})$ at $9.5 \mathrm{~mL} / \mathrm{min}$. Two solvent systems, A $\left(\mathrm{H}_{2} \mathrm{O}\right.$ with $0.05 \%$ TFA) and $B$ $\left(\mathrm{CH}_{3} \mathrm{CN}\right.$ with $0.05 \%$ TFA), were used to elute the compounds, which were monitored by UV absorbance at $254 \mathrm{~nm}$ and $214 \mathrm{~nm}$. The elution protocol for analytical HPLC starts with $90 \% \mathrm{~A}$ for $1 \mathrm{~min}$, followed by a linear gradient to $30 \% \mathrm{~A}$ over $20 \mathrm{~min}$ and at $30 \% \mathrm{~A}$ for $5 \mathrm{~min}$, to $10 \%$ A over $5 \mathrm{~min}$, and finally back to $90 \%$ A over $2 \mathrm{~min}$ ). Waters ZQ 4000 positive electrospray at cone voltage $67 \mathrm{~V}$ was used for mass spectrometry. High resolution mass analysis was performed in the Protein and Nucleic Acid Chemistry Laboratory, Washington University Medical School, St. Louis.

UV-Vis and fluorescent spectroscopic analysis: Absorbance spectra were measured on a Beckman Coulter DU 640 UV-Visible spectrophotometer. Fluorescence spectra were recorded on a Fluorolog-3 fluorophotometer (JOBIN YVON/HORIBA, Edison, New Jersey). Stock solutions $(1.0 \mathrm{mM})$ of the dyes and their conjugates were prepared by dissolving them in anhydrous DMSO (99.99\%). UV-Vis and fluorescence measurements were carried out by sequentially adding $0.5-2.0 \mu \mathrm{L}$ aliquots of the stock solutions with a micropipette into $3 \mathrm{~mL}$ of $20 \%$ aqueous DMSO solvent mixture in a quartz cuvette. The solutions were stirred briefly for equilibration prior to data acquisition. 


\section{Synthesis of 1,1,2-trimethyl[1H]-benz[e]indole-3-propanoic acid (1a)}

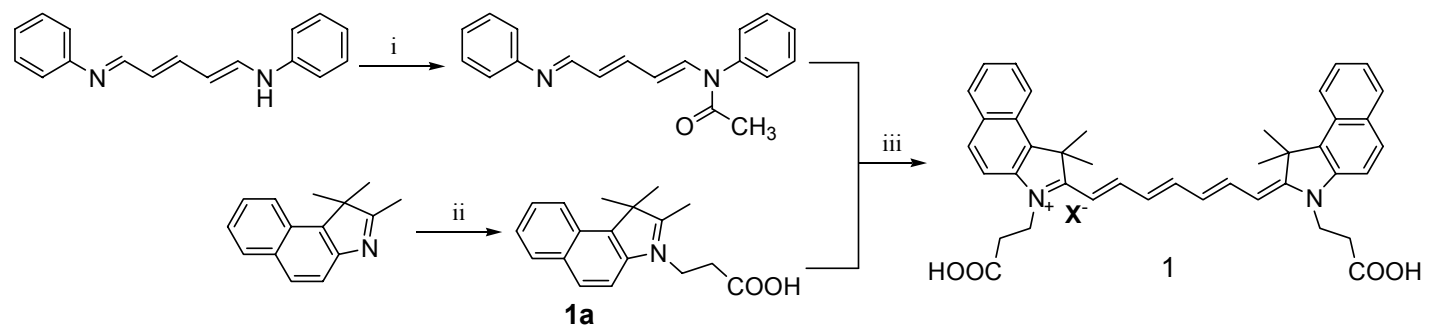

Reagents and condition: i. acetic anhydride/DIEA/DCM;ii. 3-bromopropanoic acid/1,2-dichlorobenzene $/ 110^{\circ} \mathrm{C} ; 3 . \mathrm{CH}_{3} \mathrm{COONa} / \mathrm{CH}_{3} \mathrm{CN} / \mathrm{H}_{2} \mathrm{O} /$ refluxed.

A mixture of 1,1,2-trimethyl-[1H]-benz[e]indole $(40.0 \mathrm{~g}, 19.11 \mathrm{mmol})$ and 3bromopropanoic acid (40.0 g, $26.15 \mathrm{mmol})$ in 1,2-dichlorobenzene $(200 \mathrm{~mL})$ was heated and stirred at $110{ }^{\circ} \mathrm{C}$ for $18 \mathrm{~h}$. After the resulting mixture was cooled to room temperature, the precipitate was collected by filtration, triturated with DCM thoroughly to remove the un-reacted material, and dried under vacuum to afford $57.0 \mathrm{~g}$ of light brown powder (82.4\%). ESI-MS: observed [MH] $]^{+} 281.3$

\section{Synthesis of cypate (1)}

A solution of $\mathrm{Ac}_{2} \mathrm{O}(1.20 \mathrm{~g}, 11.75 \mathrm{mmol})$ in DCM $(5 \mathrm{~mL})$ was added dropwise to a cooled, suspension of glutaconaldehyde dianil monohydrochloride $(2.84 \mathrm{~g}, 9.97 \mathrm{mmol})$ and DIEA $(2.60 \mathrm{~g}, 20.11 \mathrm{mmol})$ in DCM $(20 \mathrm{~mL})$. The resulting clear solution was stirred for another $1 \mathrm{~h}$ and added dropwise to a refluxing solution of 1a $(8.2 \mathrm{~g}, 22.64$ mmol) and sodium acetate $(3.2 \mathrm{~g}, 39.01 \mathrm{mmol})$ in acetonitrile/water $(95 / 5 \mathrm{~mL})$. The mixture was refluxed for $16 \mathrm{~h}$, cooled, filtered, and washed with acetonitrile, $5 \% \mathrm{HCl}$ solution and ethyl ether. About $6 \mathrm{~g}(85 \%)$ of 1 was obtained. ESI-MS: observed $[\mathrm{MH}]^{+}$ 625.3
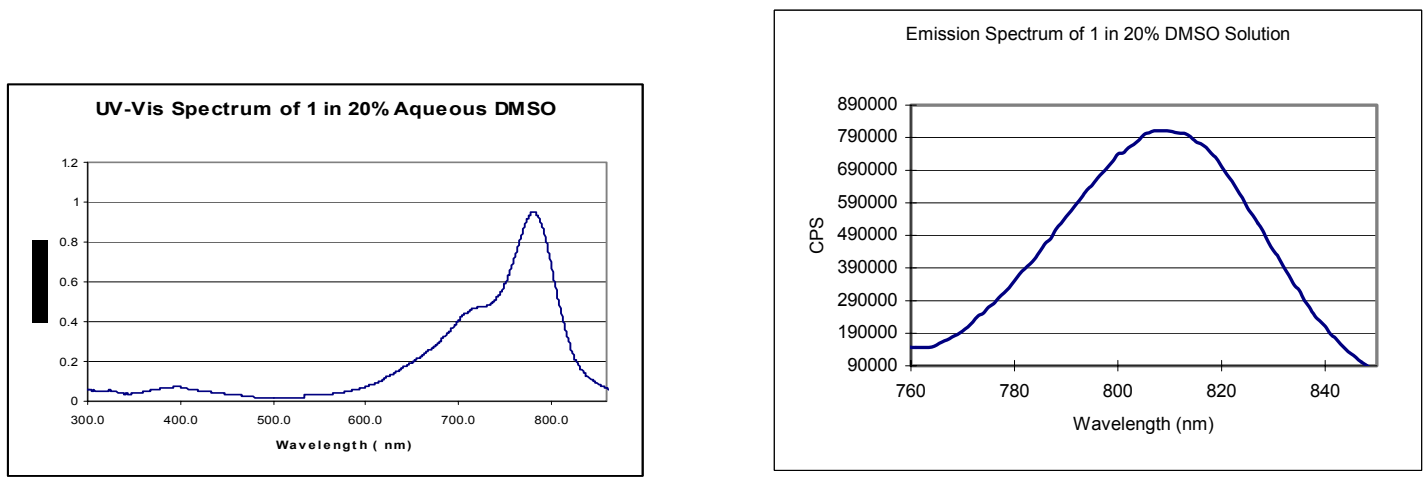
Tricarboxylic acid-containing Cypate derivative (2)

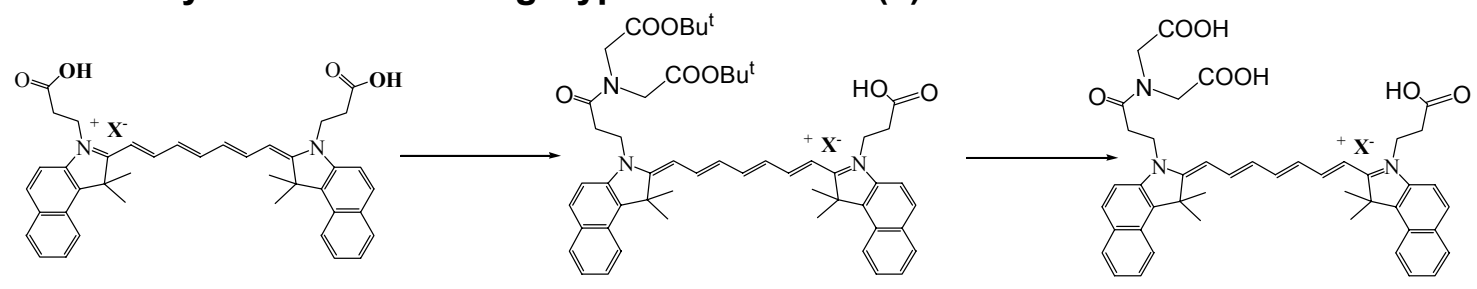

To a cooled solution of 1 (352.5 $\mathrm{mg}, 0.5 \mathrm{mmol})$ in DMF $(15 \mathrm{~mL})$ was added EDCl (114.6 mg, $0.6 \mathrm{mmol})$. After $20 \mathrm{~min}$, HOBt $(81.2 \mathrm{mg}, 0.60 \mathrm{mmol})$ and di-tert-butyl iminodiacetate $(147.0 \mathrm{mg}, 0.60 \mathrm{mmol})$ were added. The mixture was stirred at room temperature for $2 \mathrm{~h}$ and concentrated. The residue was dissolved in DCM $(35 \mathrm{~mL})$, washed with $1 \mathrm{~N} \mathrm{HCl}$ solution $(3 \times 15 \mathrm{~mL})$ and brine, and dried over MgSO4. The filtrate was concentrated and purified by flash column chromatography using dichloromethane/methanol $(100: 6 \mathrm{v} / \mathrm{v})$ to elute $153.8 \mathrm{mg}(33 \%)$. ES-MS: observed $[\mathrm{MH}]^{+}$ 852.4

The above compound (70 $\mathrm{mg}, 0.075 \mathrm{mmol})$ was dissolved in TFA $(10 \mathrm{~mL})$ and stirred for $1 \mathrm{~h}$, concentrated, and dried to afford $59 \mathrm{mg}$ of 2 , which was further purified by HPLC. ES-MS: observed [MH] ${ }^{+} 740.3$; HR-MS: 740.2987
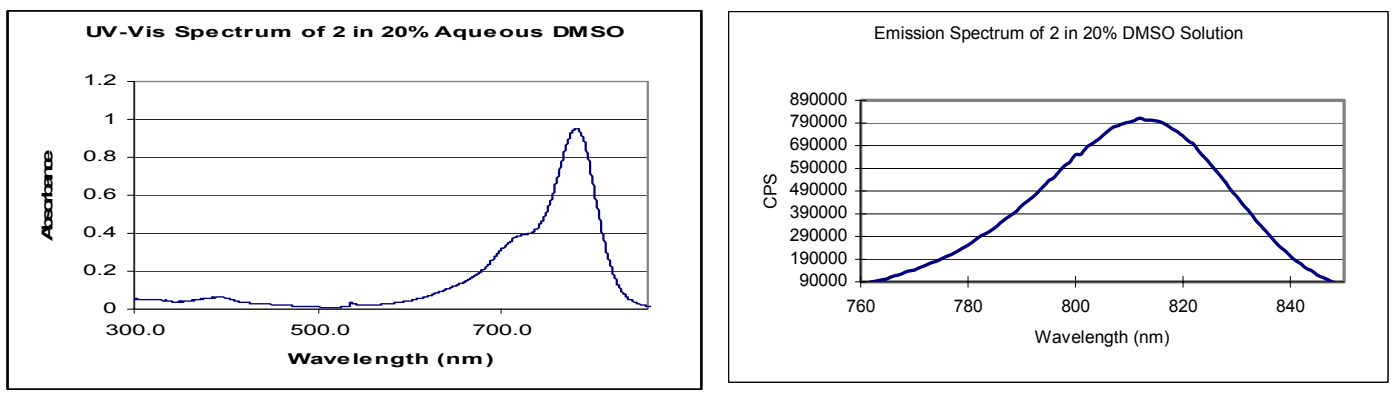

\section{Tetracarboxylic acid-containing Cypate derivative (3)}

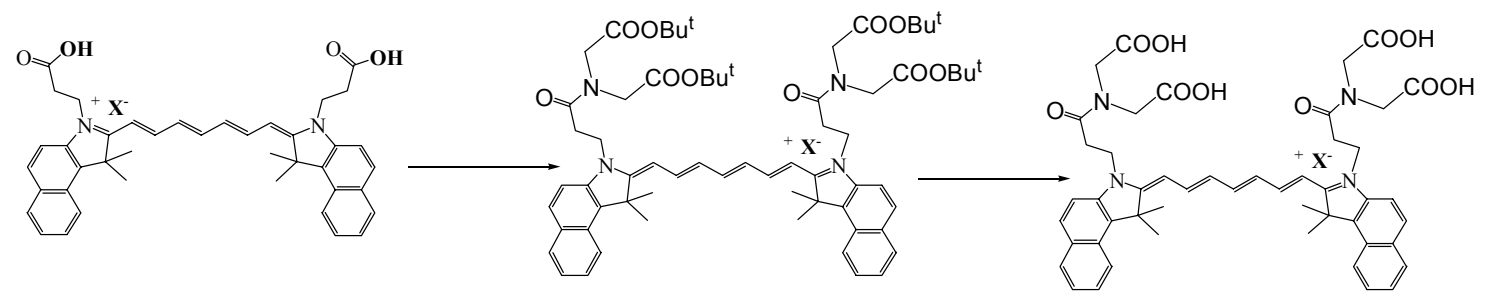

To a cooled $\left(0-5{ }^{\circ} \mathrm{C}\right)$ solution of $1(352.5 \mathrm{mg}, 0.5 \mathrm{mmol})$ in DMF (15 mL) was added EDCl (382.0 mg, $2.0 \mathrm{mmol})$ and HOBt $(270 \mathrm{mg}, 2.0 \mathrm{mmol})$. After $15 \mathrm{~min}$, di-tertbutyl iminodiacetate $(490.0 \mathrm{mg}, 2.0 \mathrm{mmol})$ was added. The mixture was stirred at room temperature for $3 \mathrm{~h}$ and concentrated. The residue was dissolved in DCM (35 mL), washed with $1 \mathrm{~N} \mathrm{HCl}$ solution $(3 \times 15 \mathrm{~mL})$ and brine, and dried over MgSO4. The filtrate was concentrated and purified by flash column chromatography using $\mathrm{CH}_{3} \mathrm{OH} / \mathrm{CH}_{2} \mathrm{Cl}_{2}$ $(4: 100 \mathrm{v} / \mathrm{v})$ to elute $348 \mathrm{mg}(1159,60 \%)$ of protected 3. ES-MS: observed [MH] ${ }^{+} 1079.5$

The above compound (200 mg, $0.17 \mathrm{mmol})$ was dissolved in TFA (30 mL) and stirred for $1 \mathrm{~h}$, concentrated, and dried to afford $154 \mathrm{mg} \mathrm{(97 \% )} \mathrm{of} \mathrm{3,} \mathrm{which} \mathrm{was} \mathrm{further}$ purified by HPLC. ES-MS: observed $[\mathrm{MH}]^{+} 855.2$ 

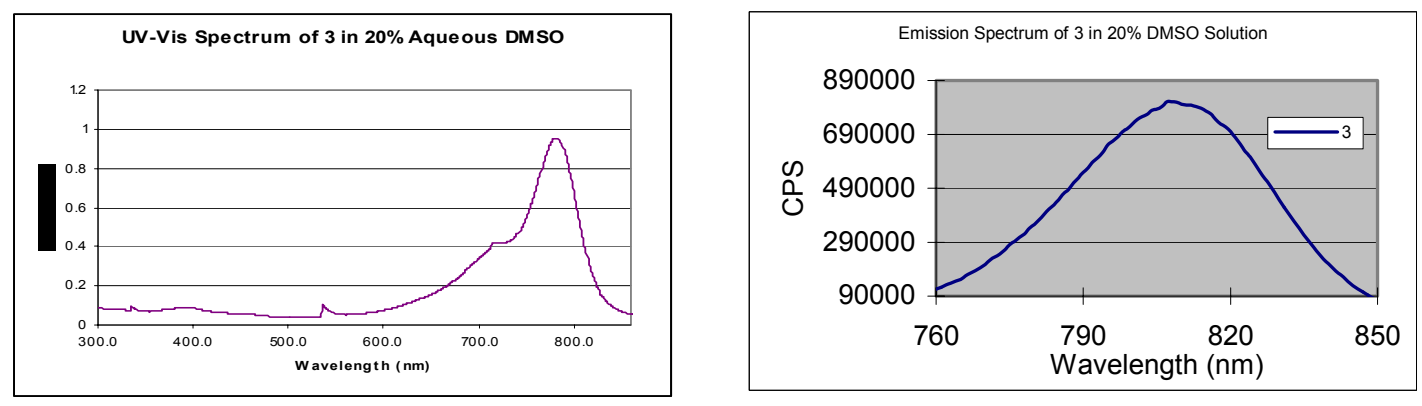

\section{Hexa-carboxylic acid-containing Cypate derivative (4)}
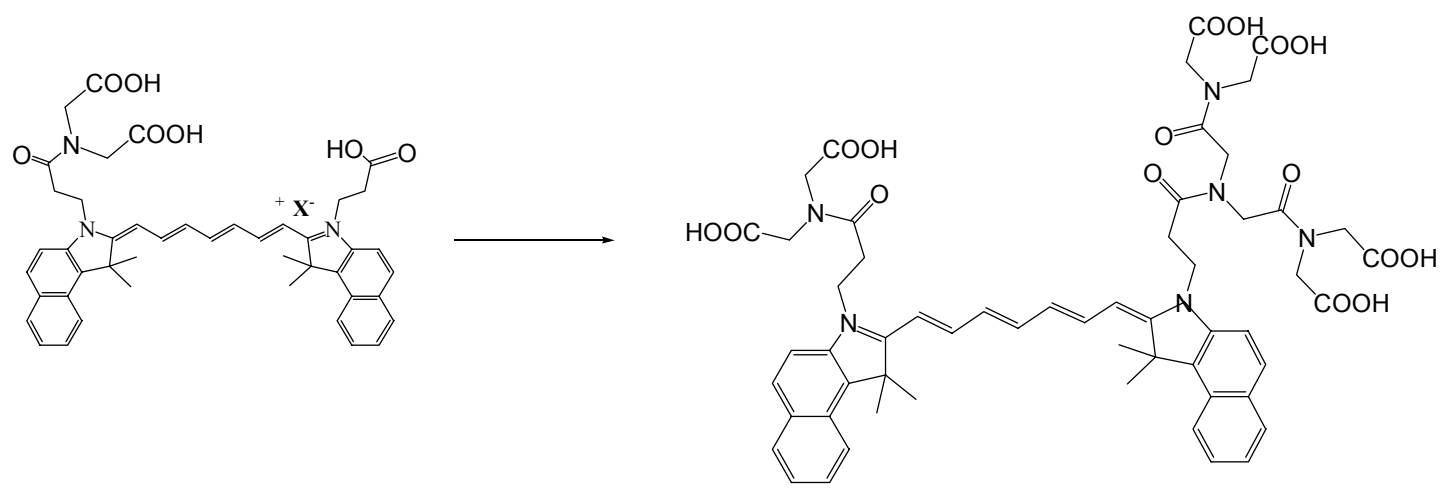

Di-tert-butyl iminodiacetate $(352.8 \mathrm{mg}, 1.44 \mathrm{mmol})$ was added dropwise to a cooled $\left(-15^{\circ} \mathrm{C}\right)$ and stirred solution of $2(130 \mathrm{mg}, 0.16 \mathrm{mmol})$, EDCl $(275.1 \mathrm{mg}, 1.44$ $\mathrm{mmol}$ ) and HOBt (194.4 mg, $1.44 \mathrm{mmol})$ in DMF $(8 \mathrm{~mL})$. The mixture was stirred at room temperature for $8 \mathrm{~h}$ and concentrated. The residue was dissolved in DCM, washed with $1 \mathrm{~N} \mathrm{HCl}$ solution, $10 \% \mathrm{NaHCO}_{3}$ and brine, and dried over $\mathrm{MgSO}_{4}$. The filtrate was concentrated and purified by flash column chromatography using $\mathrm{CH}_{3} \mathrm{OH} / \mathrm{CH}_{2} \mathrm{Cl}_{2}(4: 100$ $\mathrm{v} / \mathrm{v})$ to elute $72 \mathrm{mg}(30 \%)$. ES-MS observed $[\mathrm{MH}]^{+} 1422.6$

The above compound $(15 \mathrm{mg}, 0.01 \mathrm{mmol})$ was dissolved in TFA $(10 \mathrm{~mL})$ and stirred for $1 \mathrm{~h}$, concentrated, and dried to afford 4 (11 $\mathrm{mg}, 95 \%)$ which was further purified by HPLC. ES-MS: observed [MH] ${ }^{+} 1085.2$
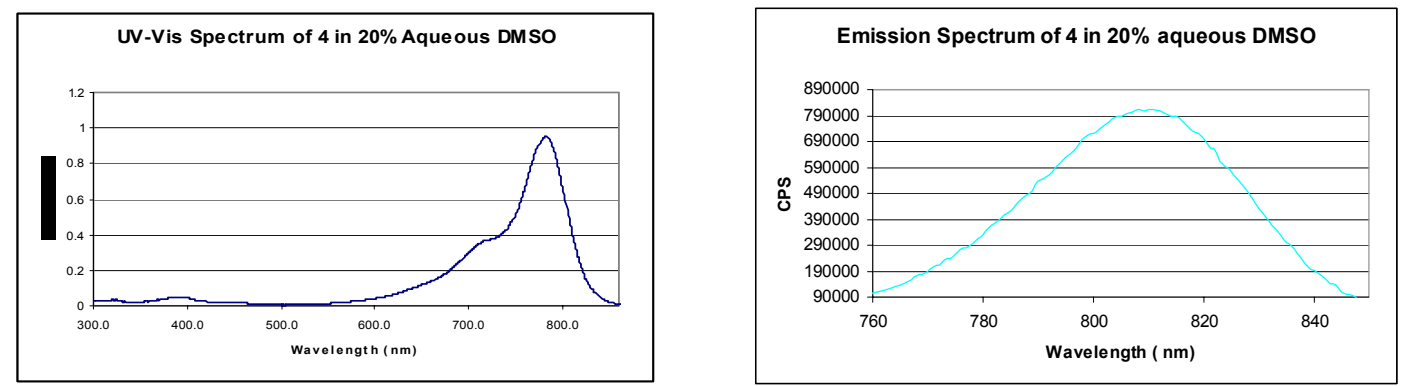

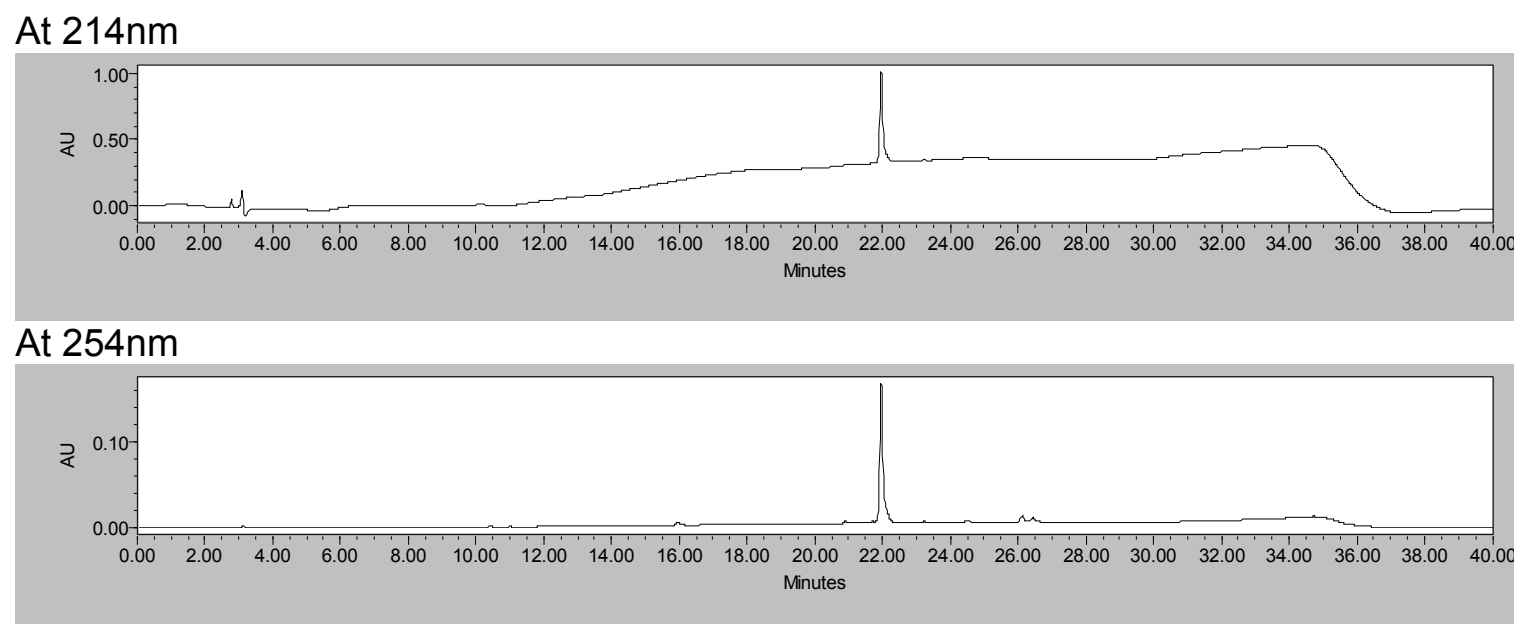

Octa-carboxylic acid-containing Cypate derivative (5)

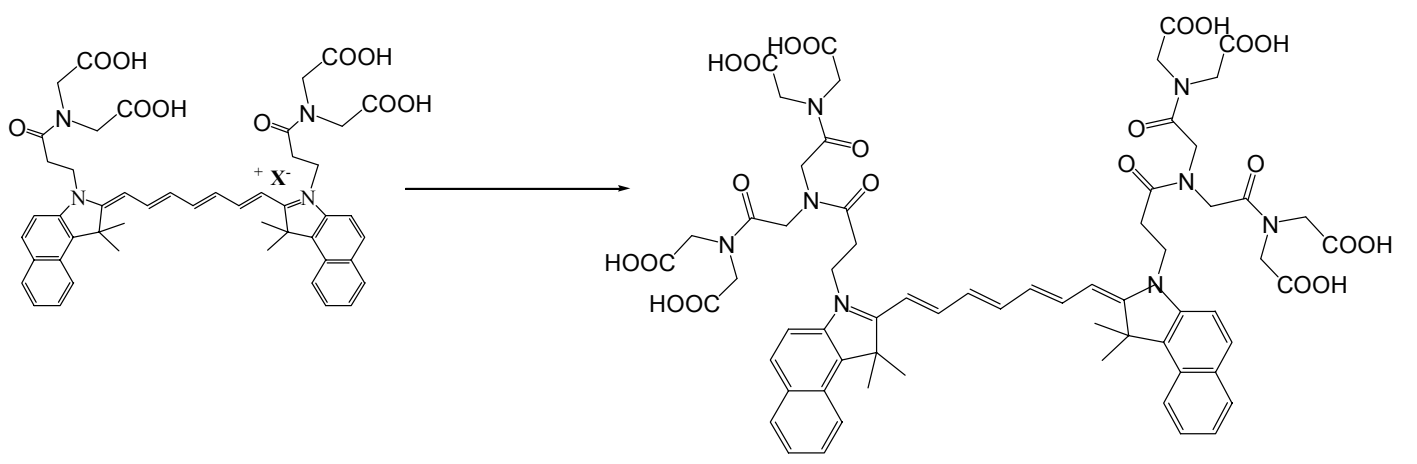

To a cooled $\left(-5{ }^{\circ} \mathrm{C}\right)$ and stirred solution of 3 (94 $\left.\mathrm{mg}, 0.10 \mathrm{mmol}\right)$, EDCl (229.2 $\mathrm{mg}$, $1.20 \mathrm{mmol}$ ) and HOBt (162 $\mathrm{mg}, 1.20 \mathrm{mmol})$ in DMF $(5 \mathrm{~mL})$, was added dropwise a solution of di-tert-butyl iminodiacetate $(196.0 \mathrm{mg}, 0.80 \mathrm{mmol})$ in DMF $(3 \mathrm{~mL})$. The mixture was stirred at room temperature for $8 \mathrm{~h}$ and concentrated. The residue was dissolved in DCM $(35 \mathrm{~mL})$, washed with $1 \mathrm{~N} \mathrm{HCl}$ solution, $10 \% \mathrm{NaHCO}_{3}$ and brine, and dried over $\mathrm{MgSO}_{4}$. The filtrate was concentrated and purified by flash column chromatography using $\mathrm{CH}_{3} \mathrm{OH} / \mathrm{CH}_{2} \mathrm{Cl}_{2}$ (v:v 5:100) to elute $55.0 \mathrm{mg}$ (30\%). ES-MS: observed $[\mathrm{MH}]^{+} 1764.6$

The above product $(25 \mathrm{mg}, 0.0136 \mathrm{mmol})$ was dissolved in TFA $(10 \mathrm{~mL})$ and stirred for $2 \mathrm{~h}$, concentrated, and dried to afford 5 (18 mg, 95\%), which was further purified by HPLC. ES-MS: observed [MH] 1315.2; HR-MS: 1315.5061
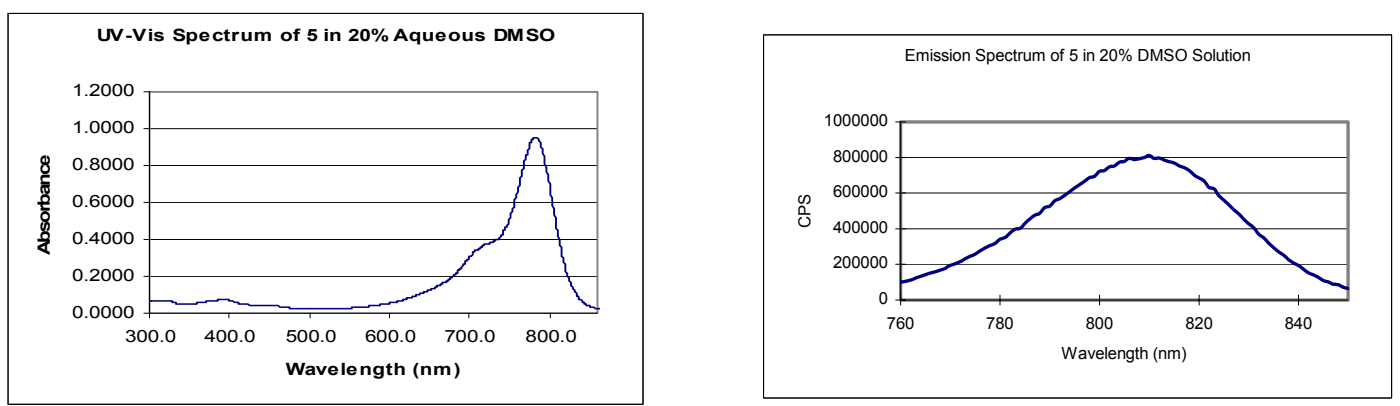


\section{At $214 \mathrm{~nm}$}

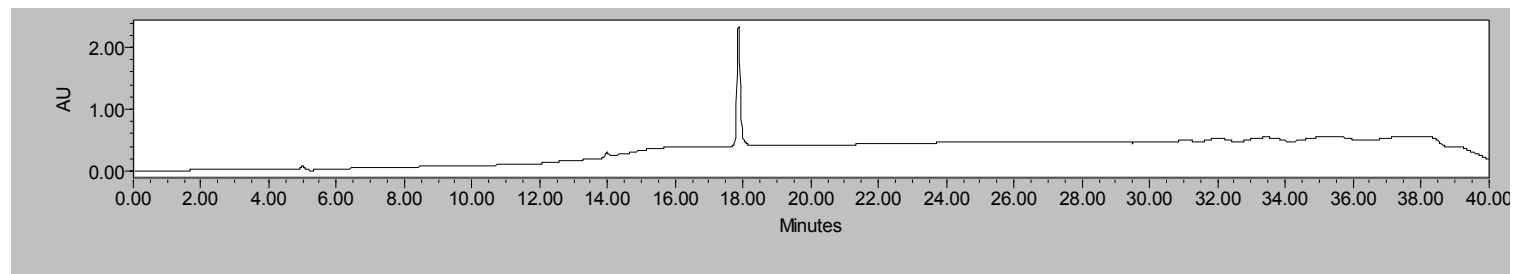

At $254 \mathrm{~nm}$

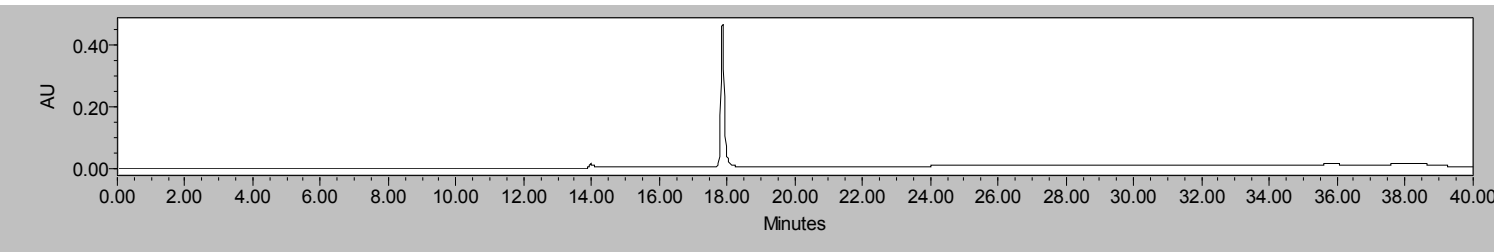

\section{Mono-D-(+)-Glucosamine-containing Cypate (6)}
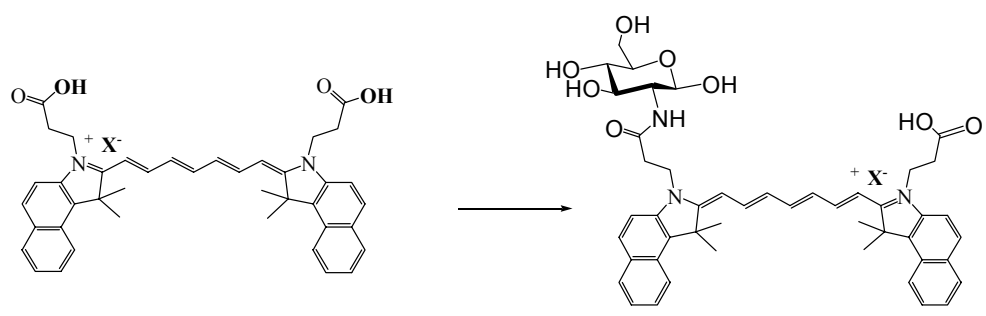

To a cooled $\left(-5^{0} \mathrm{C}\right)$ solution of $1(15 \mathrm{mg}, 0.0213 \mathrm{mmol})$, HBTU ( $10.26 \mathrm{mg}, 0.027$ $\mathrm{mmol})$ and HOBt $(3.7 \mathrm{mg}, 0.027 \mathrm{mmol})$ in DMF $(5 \mathrm{~mL})$ was added a solution of D-(+) glucosamine. $\mathrm{HCl}(12.0 \mathrm{mg}, 0.054 \mathrm{mmol})$ and DIEA (14 mg, $0.108 \mathrm{mmol})$ in DMSO (1 $\mathrm{mL})$. The mixture was stirred at room temperature for $2 \mathrm{~h}$ and added into ether $(25 \mathrm{~mL})$. The precipitate was collected and purified by HPLC $\left(\mathrm{CH}_{3} \mathrm{CN} / \mathrm{H}_{2} \mathrm{O}\right.$ from $10 \%-80 \%$ of $\mathrm{A}$ over $30 \mathrm{~min})$ to afford $2.4 \mathrm{mg}(13 \%)$ of 6 . ES-MS observed $[\mathrm{MH}]^{+} 786.3$; HR-MS: 786.4157
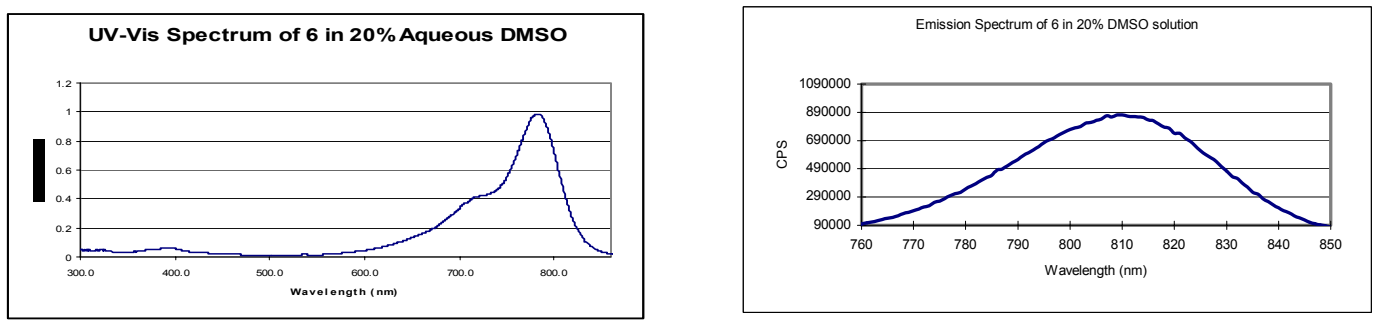

At $214 \mathrm{~nm}$

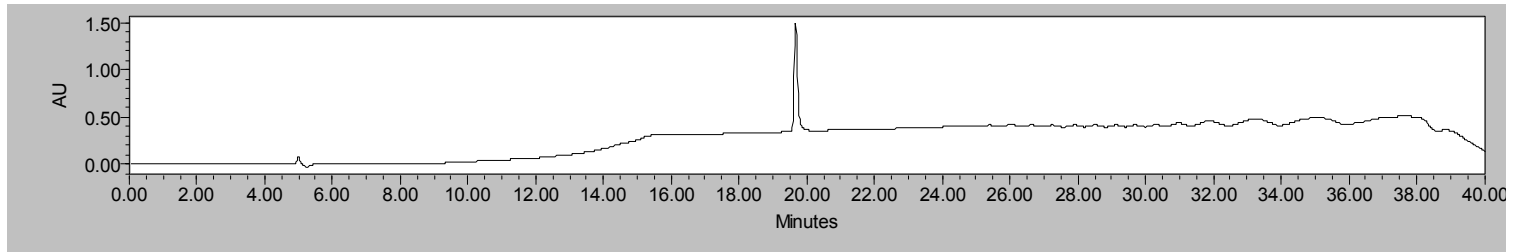




\section{At $254 \mathrm{~nm}$}

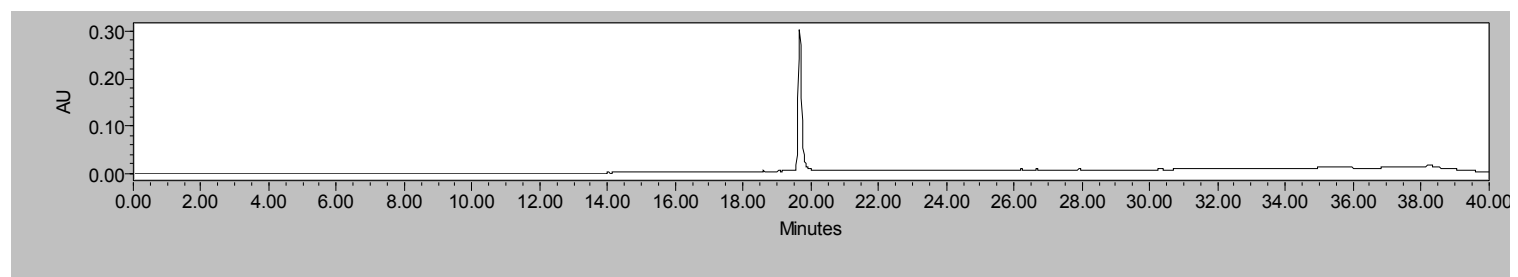

\section{Di-D-(+)-Glucosamine-containing derivative of Cypate (7)}
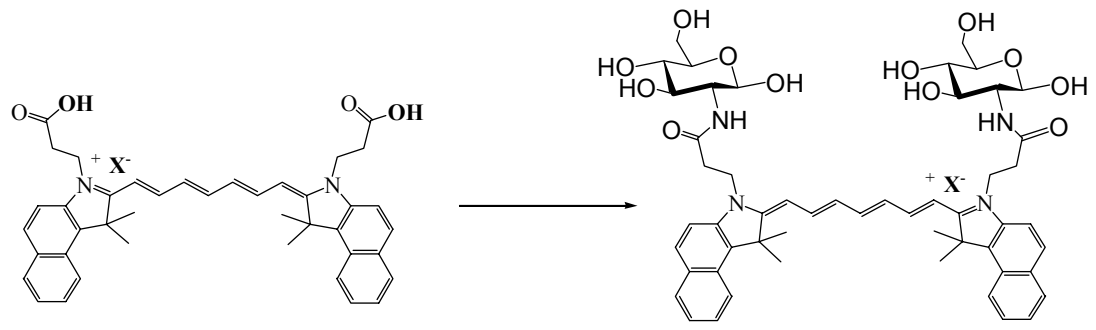

To a cooled solution of 1 (15 mg, $0.0213 \mathrm{mmol}), \mathrm{HBTU}(25.8 \mathrm{mg}, 0.068 \mathrm{mmol})$ and HOBt $(9.2 \mathrm{mg}, 0.068 \mathrm{mmol})$ in DMF $(3 \mathrm{~mL})$ was added a solution of D-(+) glucosamine. $\mathrm{HCl}(32.4 \mathrm{mg}, 0.15 \mathrm{mmol})$ and DIEA (36.5 mg, $0.28 \mathrm{mmol})$ in DMSO (1 $\mathrm{mL})$. The mixture was stirred at room temperature for $2 \mathrm{~h}$ and added into ether $(25 \mathrm{~mL})$. The precipitate was collected and purified by HPLC $\left(\mathrm{CH}_{3} \mathrm{CN} / \mathrm{H}_{2} \mathrm{O}\right.$ from $10 \%-80 \%$ over 30 $\mathrm{min})$ to afford $6.6 \mathrm{mg} \mathrm{(30 \% )}$ of 7. ES-MS observed [MH] $]^{+}$: 947.4; HR-MS: 947.5096
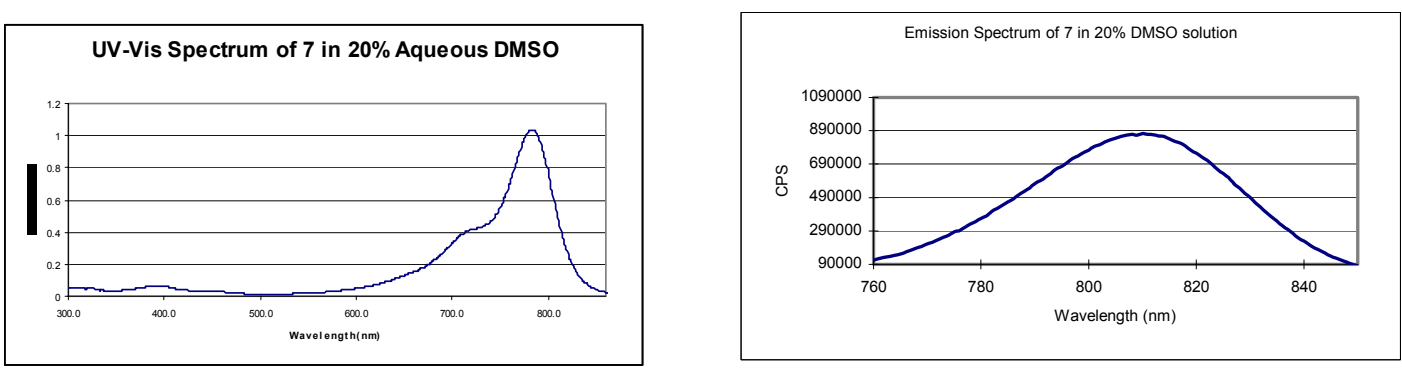

Detected at $214 \mathrm{~nm}$

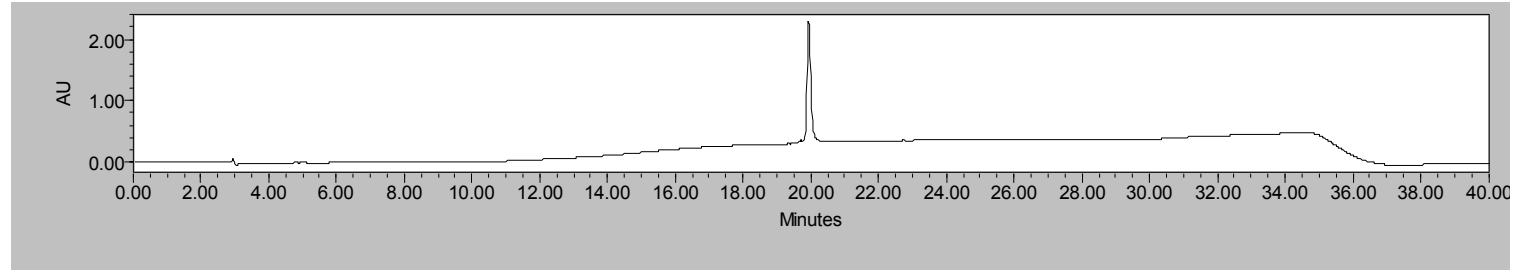




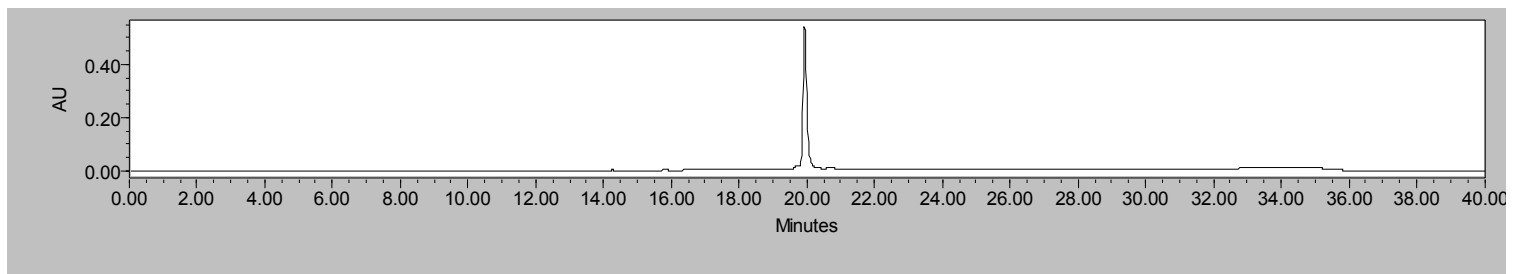

Tri-D-(+)-Glucosamine-containing derivative of Cypate (8)

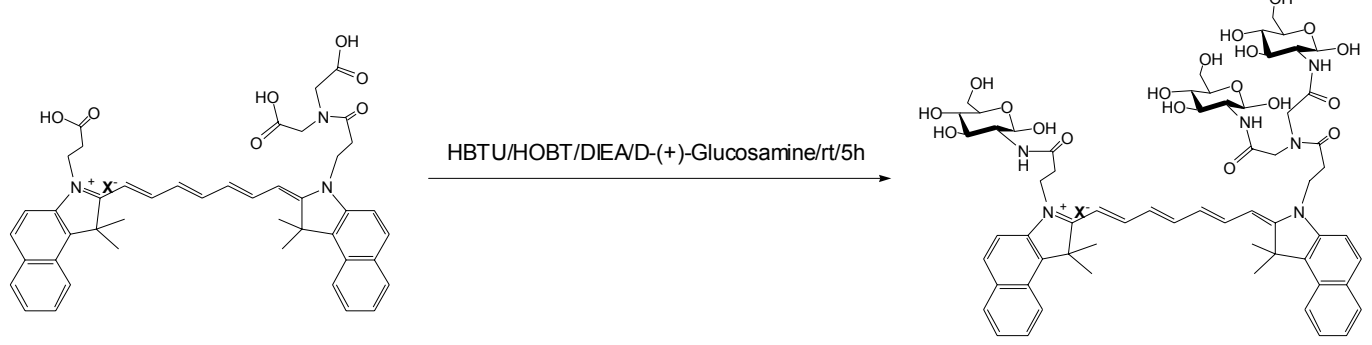

A solution of D-(+) glucosamine. $\mathrm{HCl}(43.2 \mathrm{mg}, 0.20 \mathrm{mmol})$ and DIEA (52.0 $\mathrm{mg}$, $0.40 \mathrm{mmol})$ in DMSO $(1.5 \mathrm{~mL})$ was added to a cooled solution of 2 (15 mg, 0.0183 $\mathrm{mmol})$, HBTU (38.0 mg, $0.10 \mathrm{mmol})$ and HOBt $(13.5 \mathrm{mg}, 0.10 \mathrm{mmol})$ in DMF (3 mL). The mixture was stirred at room temperature for $2 \mathrm{~h}$ and added into ether $(25 \mathrm{~mL})$. The precipitate was collected by filtration and purified by HPLC to afford $6.0 \mathrm{mg} \mathrm{(25 \% )}$ of 8 . ES-MS observed [MH] ${ }^{+}: 1223.5$; HR-MS: 1223.4759
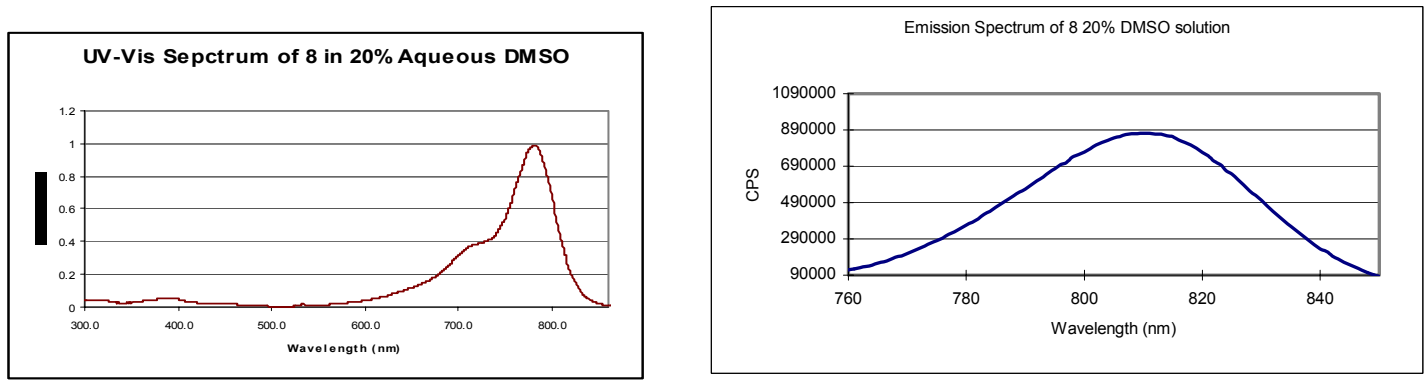

\section{At $214 \mathrm{~nm}$}

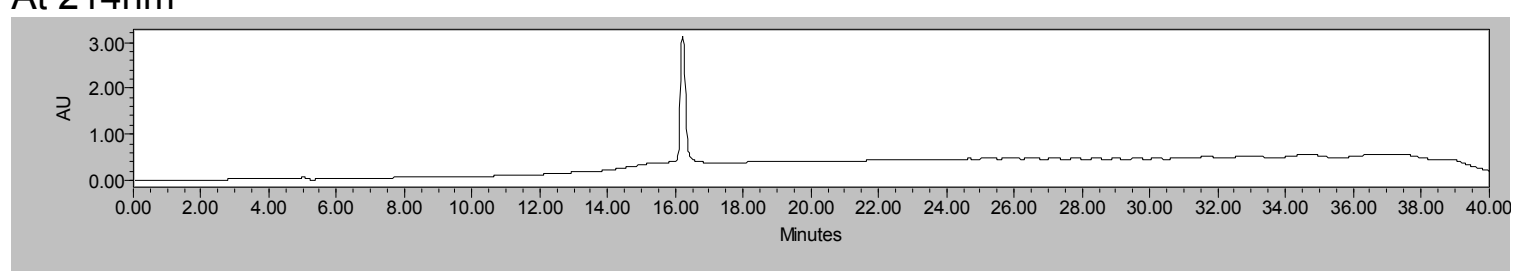

\section{At $254 \mathrm{~nm}$}

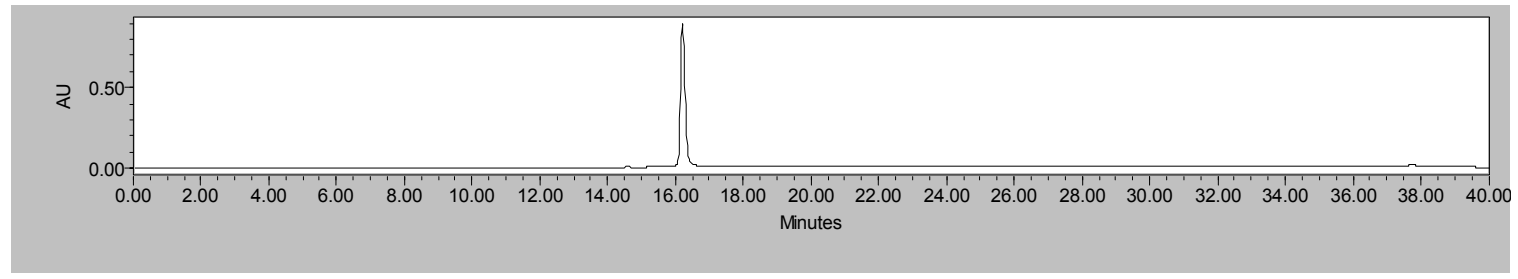


Tetra-D-(+)-Glucosamine-containing derivative of Cypate (9)
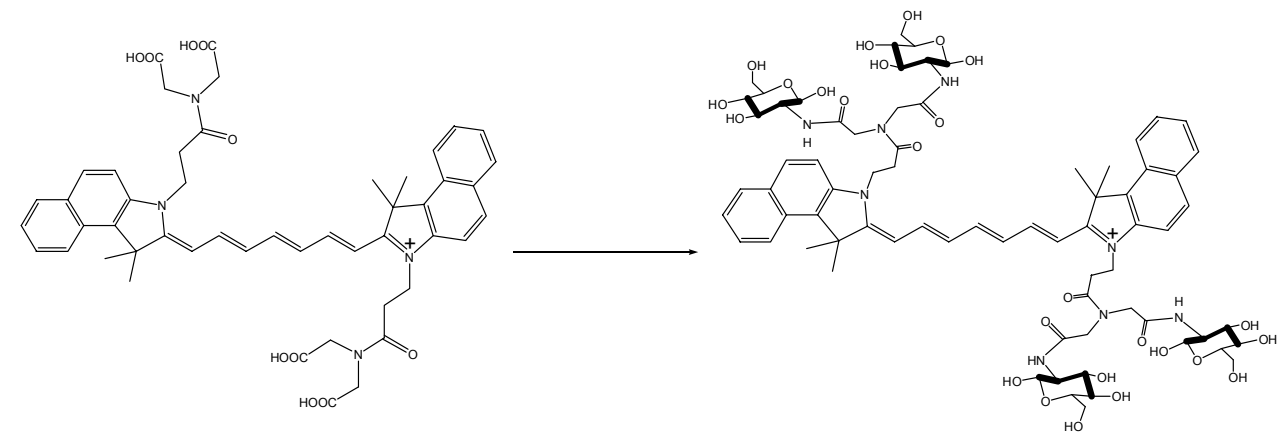

To a cooled $\left(-5^{\circ} \mathrm{C}\right)$ stirred solution of $3(16 \mathrm{mg}, 0.0171 \mathrm{mmol})$, HBTU $(129.2 \mathrm{mg}$, $0.34 \mathrm{mmol}$ ) and HOBt $(46.0 \mathrm{mg}, 0.34 \mathrm{mmol})$ in DMF ( $3 \mathrm{~mL}$ ) was added a solution of D(+) glucosamine. $\mathrm{HCl}(73.5 \mathrm{mg}, 0.34 \mathrm{mmol})$ and DIEA (129.0 mg, $1.0 \mathrm{mmol})$ in DMSO $(1.5 \mathrm{~mL})$. The mixture was stirred for $2 \mathrm{~h}$ and added into ether $(50 \mathrm{~mL})$. The precipitate was collected and purified by HPLC to afford $7.0 \mathrm{mg}(26 \%)$ of $\mathbf{9}$. ES-MS observed $[\mathrm{MH}]^{+}$ 1499.4
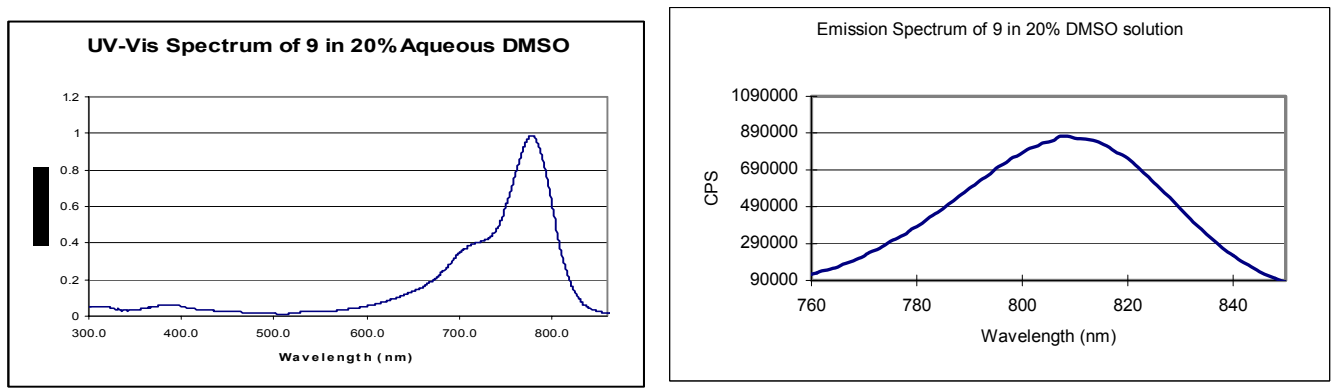

At $214 \mathrm{~nm}$

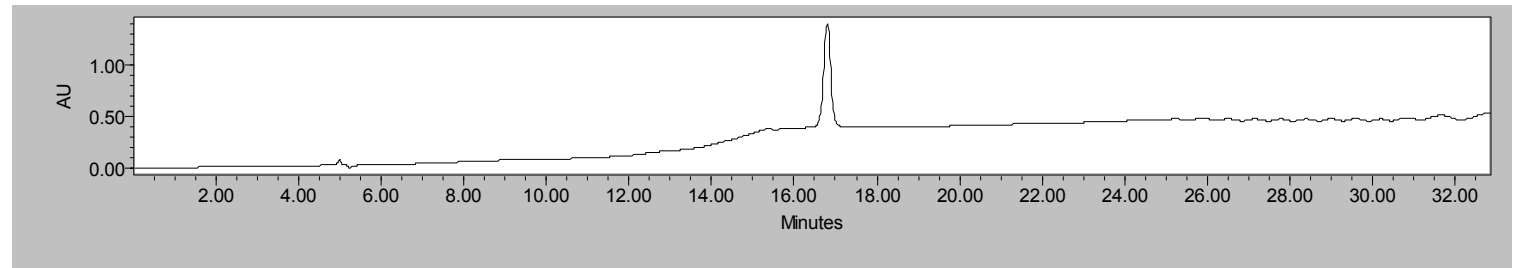

At $254 \mathrm{~nm}$

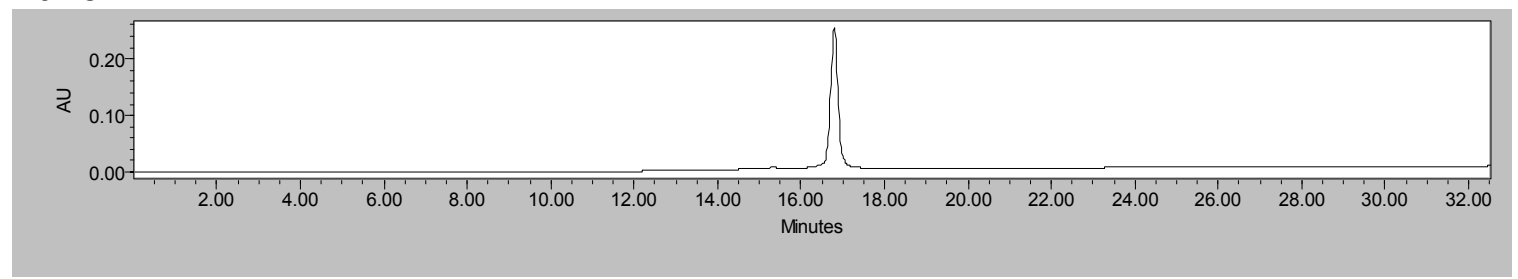


Hexa-D-(+)-Glucosamine-containing derivative of Cypate (10)

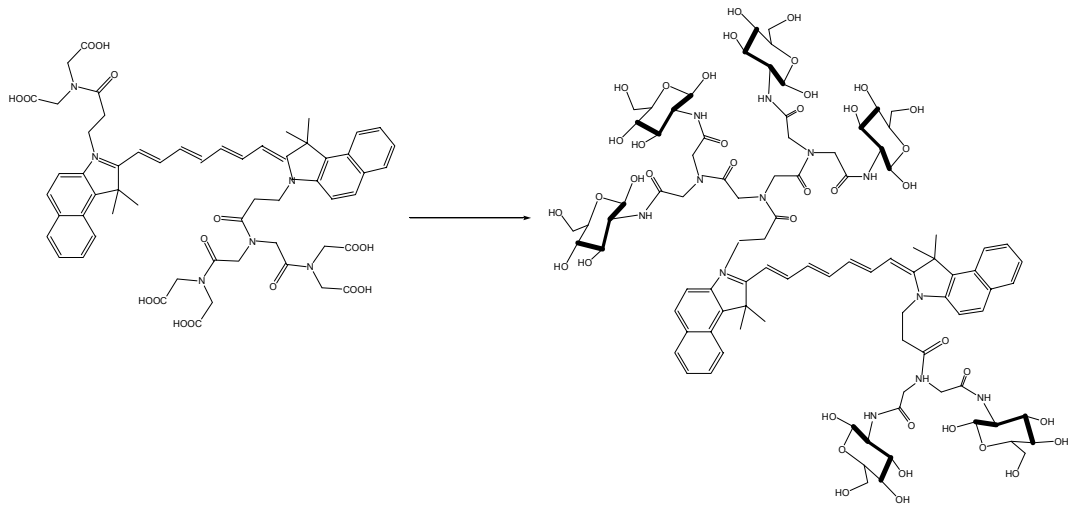

To a cooled solution of $4(20 \mathrm{mg}, 0.0172 \mathrm{mmol})$, HBTU $(380.0 \mathrm{mg}, 1.0 \mathrm{mmol})$ and HOBt (135 mg, $1.0 \mathrm{mmol})$ in DMF $(6 \mathrm{~mL})$ was added a mixture of D-(+) glucosamine. $\mathrm{HCl}$ $(216.0 \mathrm{mg}, 1.0 \mathrm{mmol})$ and DIEA $(322.5 \mathrm{mg}, 2.5 \mathrm{mmol})$ in DMSO $(8 \mathrm{~mL})$. The mixture was stirred for $2.5 \mathrm{~h}$ and added into ether $(150 \mathrm{~mL})$. The precipitate was collected by filtration and purified by HPLC to afford $7.3 \mathrm{mg}(20 \%)$ of 10 . MS observed $[\mathrm{MH}]^{+} 2052.4,\left[\mathrm{MH}_{2}\right]^{2+}$ 1026.8, $\left[\mathrm{MH}_{2}-5 \mathrm{H}_{2} \mathrm{O}\right]^{2+}$ 981.9, $\left[\mathrm{MH}_{2}-6 \mathrm{H}_{2} \mathrm{O}\right]^{2+}$ 972.9; HR-MS: 2052.5934
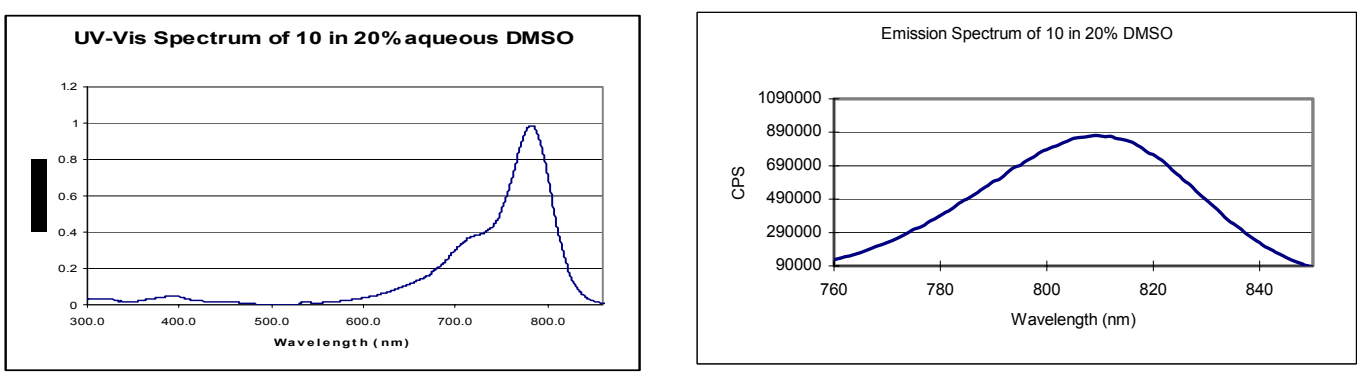

at $214 \mathrm{~nm}$

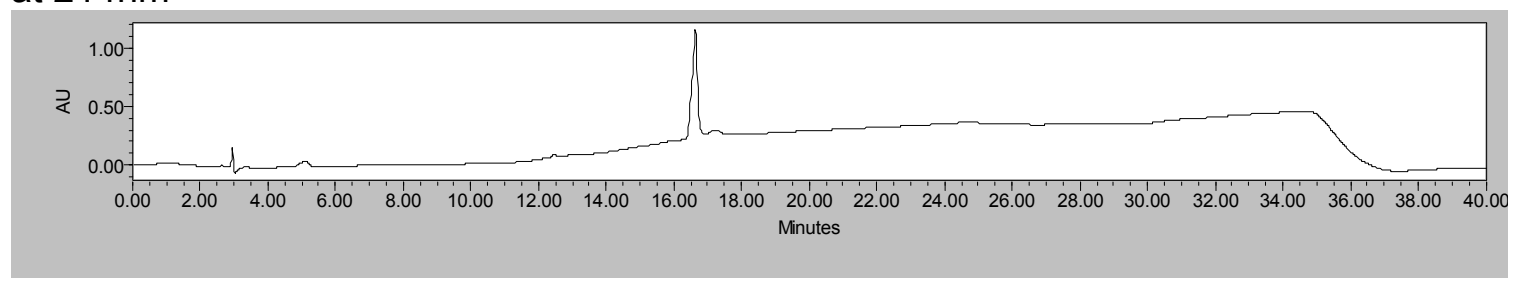

at $254 \mathrm{~nm}$

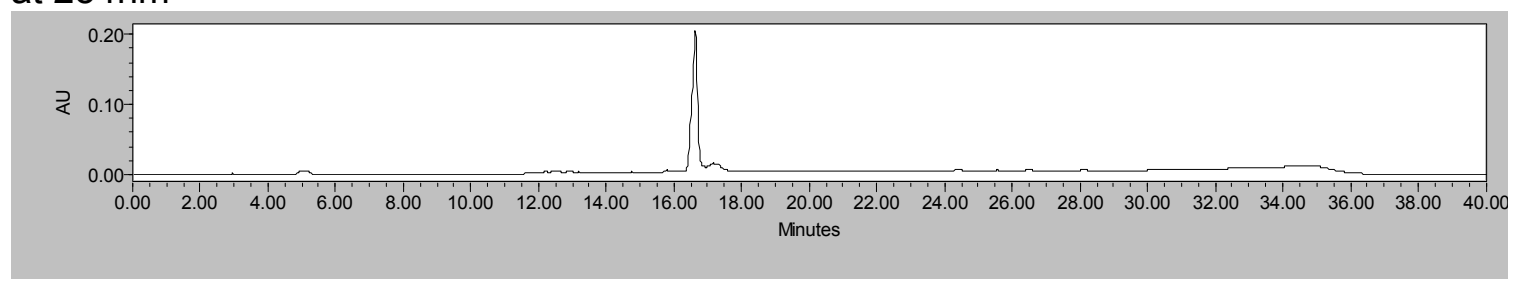




\section{Octa-D-(+)-Glucosamine-containing derivative of Cypate (11)}
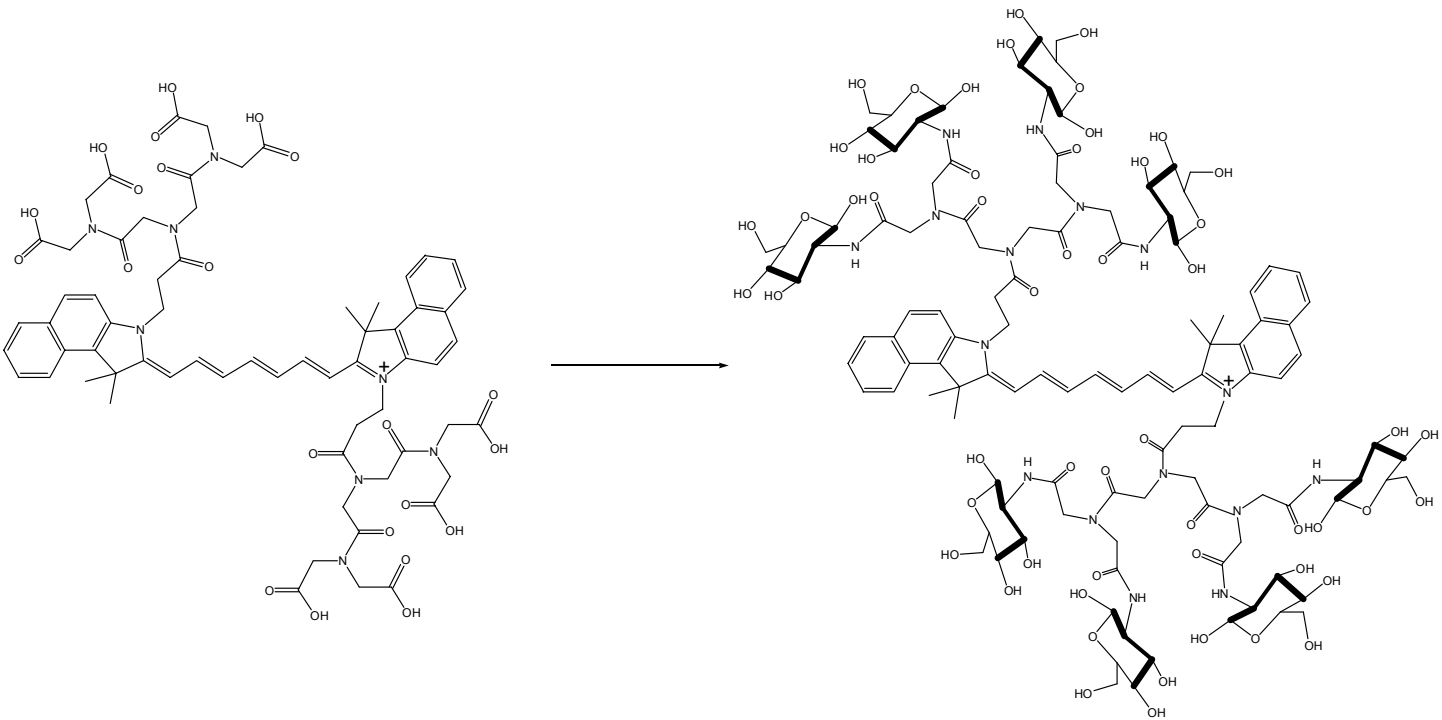

To a cooled $\left(-5^{\circ} \mathrm{C}\right)$ solution of $5(20 \mathrm{mg}, 0.0143 \mathrm{mmol})$, HBTU $(380 \mathrm{mg}, 1.0 \mathrm{mmol})$ and HOBt (135 mg, $1.0 \mathrm{mmol})$ in DMF (6 mL) was added a mixture of $\mathrm{D}-(+)$ glucosamine. $\mathrm{HCl}(432.0 \mathrm{mg}, 2.0 \mathrm{mmol})$ and DIEA (516 mg, $4.0 \mathrm{mmol})$ in DMSO (12.0 $\mathrm{mL})$. The mixture was stirred for $2.5 \mathrm{~h}$ and added into ether $(150 \mathrm{~mL})$. The precipitate was collected by filtration and purified by HPLC $\left(\mathrm{CH}_{3} \mathrm{CN} / \mathrm{H}_{2} \mathrm{O}\right.$ from $10 \%-70 \%$ over 30 $\min )$ to afford $8.0 \mathrm{mg}(21 \%)$ of 11 . ES-MS observed $[\mathrm{MH}]^{+}: 2606.5,\left[\mathrm{MH}_{2}\right]^{2+}: 1302.5$, $\left[\mathrm{MH}_{2}-\mathrm{H}_{2} \mathrm{O}\right]^{2+}: 1293.4,\left[\mathrm{MH}_{2}-2 \mathrm{H}_{2} \mathrm{O}\right]^{2+}:$ 1284.9, $\left[\mathrm{MH}_{2}-3 \mathrm{H}_{2} \mathrm{O}\right]^{2+}: 1275.6,\left[\mathrm{MH}_{2}-4 \mathrm{H}_{2} \mathrm{O}\right]^{2+}:$ 1267.0, $\left[\mathrm{MH}_{2}-5 \mathrm{H}_{2} \mathrm{O}\right]^{2+}:$ 1257.8, $\left[\mathrm{MH}_{2}-6 \mathrm{H}_{2} \mathrm{O}\right]^{2+}:$ 1248.4, $\left[\mathrm{MH}_{2}-7 \mathrm{H}_{2} \mathrm{O}\right]^{2+}:$ 1240.1; HR-MS: 2604.5407
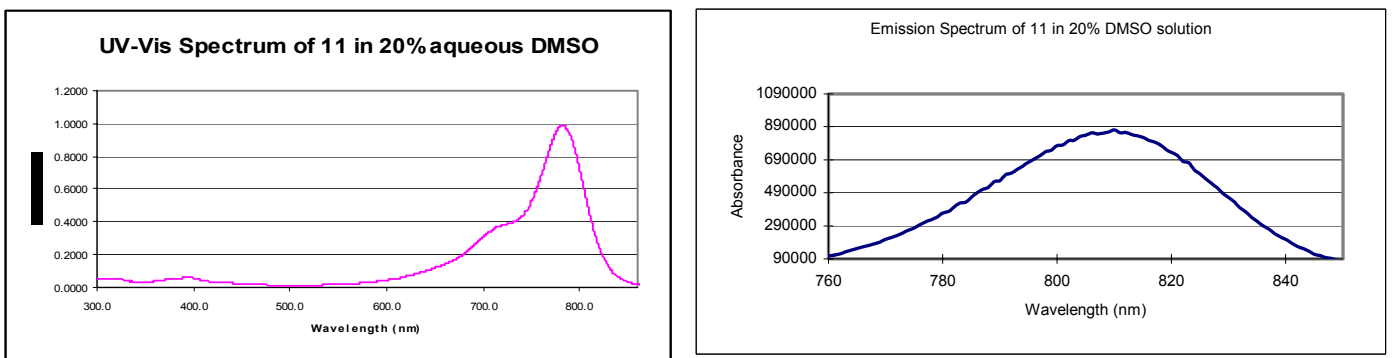

\section{At $214 \mathrm{~nm}$}

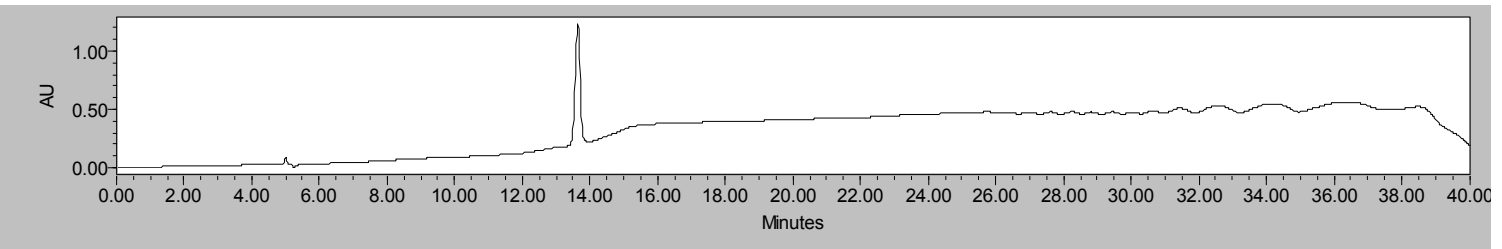

\section{At $254 \mathrm{~nm}$}

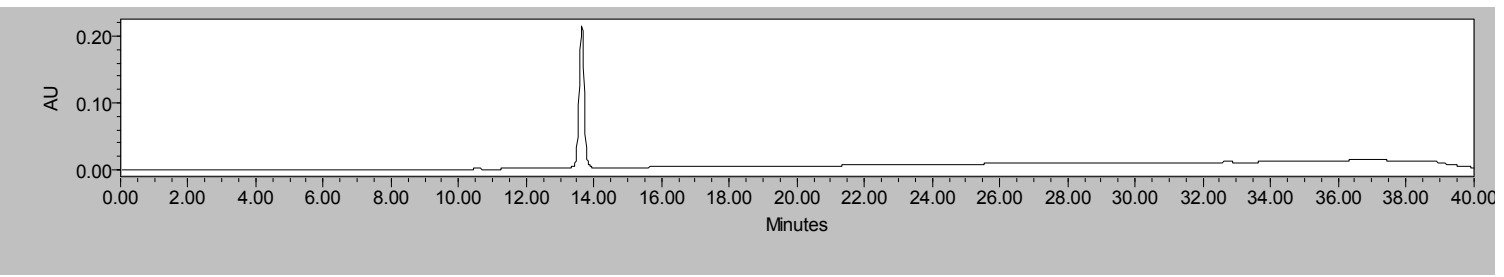




\section{Animal Imaging Procedure:}

A noninvasive in vivo continuous wave fluorescence imaging apparatus was used to assess the localization and distribution of the compounds. Briefly, $780 \mathrm{~nm}$ laser diodes launched into a fiber optic bundle was used to excite the compounds in mice. A defocusing lens in position after the bundle from each laser source expanded the beam such that the whole mouse was illuminated. The lasers generated a nominal $50 \mathrm{~mW}$ of incident power. The laser power at the output of the bundle was approximately one-half of the input power. The detector is a Princeton Instruments CCD camera. An $830 \mathrm{~nm}$ interference filter in front of the CCD camera allowed for detection of the emitted fluorescent light only. Images were acquired and processed using WinView software from Princeton Instruments. Typically, an image of the animal was taken prior to administration of the compound. Subsequent images were taken at various times after administration of the dye conjugated peptide.

Absolute quantification of fluorescence data is very difficult. For this reason, we used relative fluorescence intensity, normalized with respect to the intensity of the tumor tissue. Thin slices of tissues were taken from each organ. The organ parts were excited with a laser source and the fluorescence intensity was captured with a charge-coupled device camera. Data analysis was performed with WinView software at $95 \%$ confidence level. The values reported are the average fluorescence intensity from each organ. 